\title{
Three-dimensional inelastic numerical back-analysis of observed rock mass response to mining in an Indian mine under high-stress conditions
}

\author{
PK Rajmeny Hindustan Zinc Ltd. (Vedanta), India
}

A Vakili Mining One Consultants Pty Ltd, Australia

\begin{abstract}
Numerical modelling is increasingly being used to evaluate ground stability and to assist in the long-term planning of mining operations. However, selection of appropriate constitutive material behaviour and input parameters for the rock mass is still debated amongst the rock mechanics community. A case study of a hard rock mine practising sublevel open stoping has been simulated using $3 D$ finite difference method (FLAC3D). The mine was modelled using four types of constitutive material models - Mohr-Coulomb with post-peak cohesion-softening/friction-softening, bi-linear Mohr-Coulomb with post-peak cohesion-softening/friction-softening, Mohr-Coulomb with post-peak cohesion-softening/friction-hardening and the improved unified constitutive model (IUCM). The outcome of all approaches has been compared with measured ground performance. The comparison revealed that the numerical model using the IUCM provides the most realistic match to the observations in the mine including the failure of the crown pillars.
\end{abstract}

Keywords: high stress, numerical back analysis, constitutive model

\section{Introduction}

Depletion of ore deposits amendable for open pit mining changes the paradigm of mineral extraction. Mining activities are increasingly performed underground at greater depth and in a more challenging high-stress environment. Management of stability of underground openings is a critical task for safe and sustainable mining.

Numerical modelling is a useful tool available to rock mechanics engineers to evaluate the stability of underground openings through the mining cycle. Long-term mine planning decisions are increasingly based on predictive numerical simulations. It is important to note, however, that numerical outcomes rely heavily on the selection of material model, rock mass parameters and boundary conditions. There is also a consideration of how many parameters have to be assumed if specific values have not been determined. Industry standard procedures often involve intact rock properties being determined in the laboratory and then extrapolated to rock mass properties using the geological strength index (GSI) according to relationships provided by Hoek et al. (2002). Barton and Pandey (2011) proposed an alternative approach, using the $\mathrm{Q}$-system and the concept of cohesion-softening/friction-hardening (CSFH) proposed by Hajiabdolmajid et al. (2002) to derive the rock mass properties for the numerical modelling.

This paper investigates the suitability of various applied material models for back-analysis of a case study of sublevel open stoping at the Balaria mine in India. Numerical modelling results are compared with actual rock mass response. The material models investigated in this study include:

- Linear Mohr-Coulomb with post-peak cohesion-softening/friction-softening (CSFS).

- Bi-linear Mohr-Coulomb with post-peak cohesion-softening/friction-softening (CSFS).

- Linear Mohr-Coulomb with post-peak cohesion-softening/friction-hardening (CSFH).

- The improved unified constitutive model (IUCM) proposed by Vakili (2016). 


\section{The Balaria mine}

The Zawar group, belonging to Hindustan Zinc Ltd., is the locus of the oldest lead zinc underground mining operations in India. The Zawar is situated $43 \mathrm{~km}$ south of Udaipur (Rajasthan), in the western part of India. The group comprises of the Mochia, Balaria, Zawarmala and Baroi mines and use sublevel open stoping due to the competent nature of the rock mass. Mining in Mochia and Balaria has reached a depth of $600 \mathrm{~m}$ below the hill, while at Zawarmala and Baroi (Figure 1) mining is comparatively at a shallower depth.

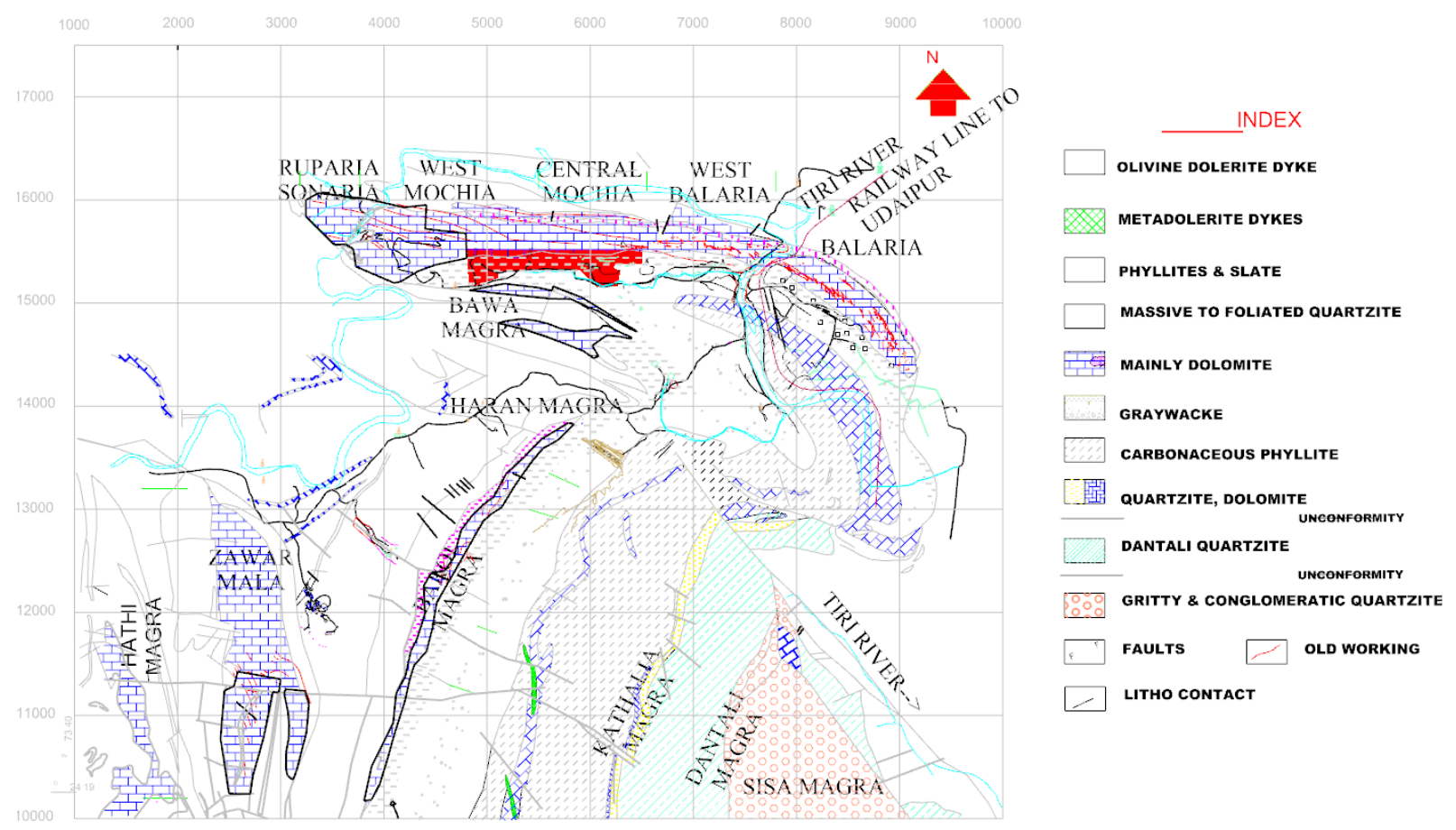

Figure 1 Regional geology of the area showing the location of the Balaria and Mochia mines of Zawar

The Zawar mining group is under a significant expansion phase and are increasing production to $4 \mathrm{Mtpa}$, from the current production level of 1.2 Mtpa. The Balaria and Mochia mines are situated in a similar limb of a geological fold (Sisa Magra anticline, Figure 1), but they are treated as two separate mines for operational convenience. Both mines are connected at various levels and are served by separate shafts and adits. A $90 \mathrm{~m}$ wide vertical pillar left at the western extremity of Balaria to protect Tiri River (and the Udaipur-Ahmedabad railway line) provides global stability to these mining sections as the main regional pillar.

Extensive open stoping in Balaria has culminated in the form of a network of open stopes surrounded by crown and rib pillars (Figures 2 and 3). These stope walls have been standing since extraction in the 1990s. To ensure stability, it is required to revaluate their global stability and then re-design the regional pillars.

Balaria consists of a series of lenses dispositioned in an en-echelon pattern, with each lens normally extracted separately. The width of these lenses varies in range from 3 to $30 \mathrm{~m}$ and dip from 60 to $75^{\circ}$ and plunge westerly at $55^{\circ}$. Mining started in Balaria with shrinkage stoping in the upper part of the main valley or adit level $378 \mathrm{mRL}$. Below the adit level, sublevel open stoping was adopted. Typical stope spans ranged from 60 to $200 \mathrm{~m}$ while stoping height varied from 60 to $120 \mathrm{~m}$ in the upper levels (up to $263 \mathrm{mRL}$ ). Later on, due to instabilities observed in stope walls, the stope span was reduced to between 60 and $90 \mathrm{~m}$ and stope heights scaled down to between 55 and $60 \mathrm{~m}$ in levels below $263 \mathrm{mRL}$.

The western stopes (under current investigation) consist of $5 \mathrm{~W}, 7 \mathrm{~W}, 8 \mathrm{~W}, 9 \mathrm{~W}$ and $10 \mathrm{~W}$ that occur in an en-echelon pattern (as seen in Figure 2). 


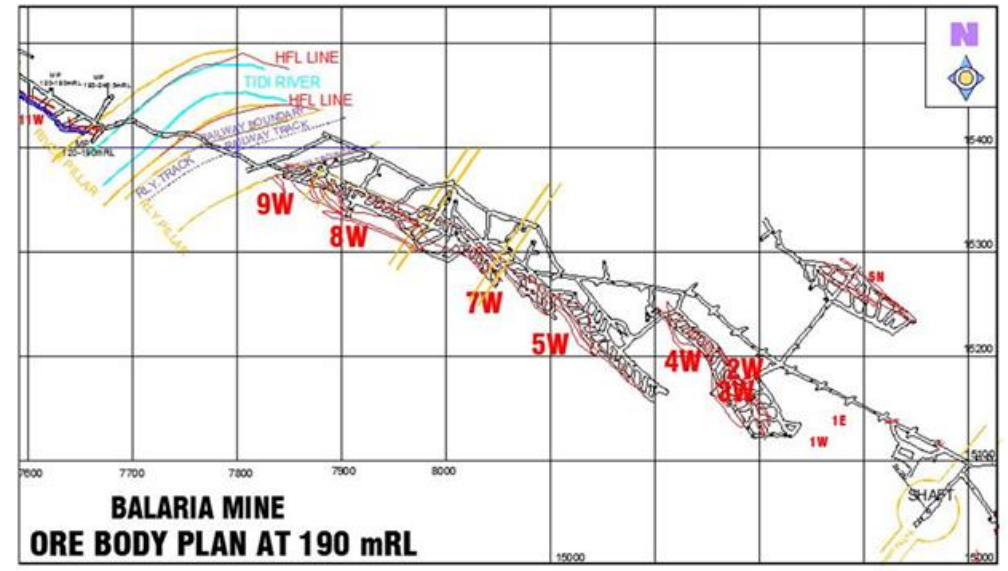

Figure 2 Step plan of the workings of the Balaria mine

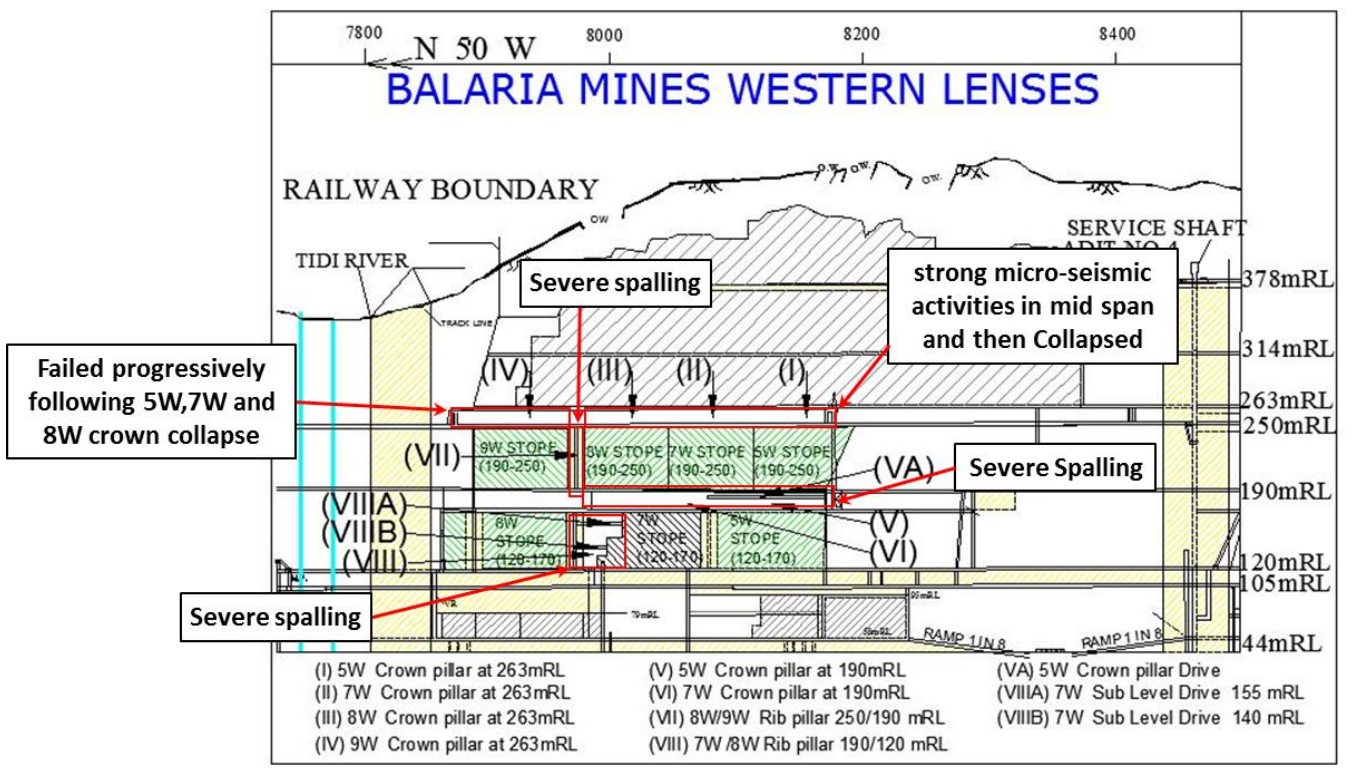

Figure 3 Long vertical section of western part of the Balaria mine

\subsection{Geology and geotechnical conditions}

The rocks of the Zawar area form a part of the Aravalli system of middle Pre-Cambrian age and overlie a banded gneissic complex. The main rocks in the area are phyllite, slate, conglomerate, greywacke, dolomite, quartzite etc. The lead-zinc mineralisation occurs in dolomite horizons. The area witnessed two major tectonic cycles, and each of the cycles resulted in a system of folding and faulting. Two major folds (Sisa Magra anticline and Zawarmala anticline) are present in this area with some other minor folds. The Mochia and Balaria mines are situated in Sisa Magra anticline, as shown on the geological map of the area (Figure 1).

Mineralisation occurs as lenses in dolomite rocks due to manifestation of the tectonic activities. As described, the western stopes of the Balaria mine truncate across the Railway pillar (Figure 2). The area is characterised by dominant horizontal stresses acting perpendicular to the strike of orebody in the Balaria Mochia region. Based on in situ stress measurement carried using hydraulic fracturing at various depths (Rummel 2005) the following stress relationships were derived (see Table 1):

- $\sigma_{\mathrm{H}}=0.048 \cdot \mathrm{H}+4.4 \mathrm{MPa} \mathrm{N}-\mathrm{S}$ (perpendicular to strike).

- $\sigma_{\mathrm{h}}=0.024 \cdot \mathrm{H}+2.2 \mathrm{MPa} \mathrm{E}-\mathrm{W}$ (parallel to strike).

- $\sigma_{\mathrm{v}}=0.029 \cdot \mathrm{H} \mathrm{MPa}$ (vertical and obtained according to overburden stress magnitude).

Where $\mathrm{H}$ is the depth below service in metres. 
Table 1 In situ stress regime determined by hydraulic fracturing technique (Rummel 2005)

\begin{tabular}{llllll}
\hline Mine & $\begin{array}{l}\text { Area of } \\
\text { measurement }\end{array}$ & $\begin{array}{l}\text { Depth } \\
(\mathbf{m})\end{array}$ & $\begin{array}{l}\boldsymbol{\sigma}_{\mathbf{1}} \\
(\mathrm{MPa})\end{array}$ & $\begin{array}{l}\boldsymbol{\sigma}_{\mathbf{1}} \\
\text { Direction }\end{array}$ & $\begin{array}{l}\boldsymbol{\sigma}_{\mathbf{3}} \\
(\mathrm{MPa})\end{array}$ \\
\hline Balaria & $378 \mathrm{mRL}$ & 96 & 8.2 & $\mathrm{~N} 110-120$ & 5.6 \\
Zawarmala & $355 \mathrm{mRL}$ & 235 & 17.7 & $\mathrm{~N} \mathrm{156-167}$ & 9.6 \\
Balaria & $105 \mathrm{mRL}$ & 315 & 20.4 & $\mathrm{~N} 110-120$ & 11.8 \\
Mochia & $39 \mathrm{mRL}$ & 500 & 28.6 & $\mathrm{~N}-\mathrm{S}$ & - \\
\hline
\end{tabular}

Laboratory tests completed on the dolomite unit were used to derive the intact rock properties including uniaxial compressive strength (UCS) $=117 \mathrm{MPa}$, Hoek-Brown constant $\left(\mathrm{m}_{\mathrm{i}}=17\right)$ and Young's modulus (40 GPa). The rock mass rating (Bieniawski 1989) of the dolomite varies from 60 to 70 (Table 2). Based on underground visual observations and scanline mapping, the number of joint sets, joint spacing and joint conditions resulted in a GSI value of 60 being assigned to the dolomite.

Table 2 Rock mass rating of the dolomite

\begin{tabular}{llll}
\hline Number & Parameter & Description & Rating \\
\hline 1 & Rock quality designation (RQD) & $60-70 \%$ & 10 \\
\hline 2 & Intact rock strength & $117 \mathrm{MPa}$ & 11 \\
\hline 3 & Joint spacing & $\begin{array}{l}\text { Two joint sets, spacing 10 and } \\
20 \mathrm{~cm}\end{array}$ & 11 \\
& & Wavy, unidirectional, smooth and & 25 \\
4 & Joint condition & no alteration & 10 \\
\hline 5 & Water condition & Wet & 67 \\
\hline
\end{tabular}

\subsection{Rock mass response to mining}

Dominant high horizontal in situ stress in the region led to ground control problems at early stages of mining. During the final stages of extraction of the $8 \mathrm{~W}$ stope on 263-190 mRL, initially, the crown pillar of the $8 \mathrm{~W} 263 \mathrm{mRL}$ experienced severe to very severe spalling at its mid-span. The crown pillar (thickness $=8$ to $10 \mathrm{~m}$ ) collapsed over a period of 48 hours. The floor of the drive situated above the crown pillar at $263 \mathrm{mRL}$ experienced heaving.

The $9 \mathrm{~W}$ crown pillar on 263-190 mRL also experienced similar conditions, however, it failed progressively. With the completion of $8 \mathrm{~W}-9 \mathrm{~W}$ stopes on 263-190 mRL, their common rib pillar and service raises experienced breakout. Following these events, the western stopes were isolated from the remainder of this mining region by creating $1.8 \mathrm{~m}$ thick reinforced concrete cement walls.

Stoping started in the lower block of 190-120 mRL by leaving a $20 \mathrm{~m}$ thick crown pillar along the entire strike length to isolate the current stoping block from the upper mined out block of 378 to $263 \mathrm{mRL}$. While carrying out extraction of the 190-120 mRL series, the $20 \mathrm{~m}$ thick crown pillar of 5W stope experienced gradual spalling and the drive on the $170 \mathrm{mRL}$ experienced roof overbreak by approximately $1.5-1.8 \mathrm{~m}$. Similarly, the $7 \mathrm{~W}$ crown also experienced the same rock mass response. In particular, the western part of the 7W stope experienced very severe spalling and led to premature termination of mining resulting in the need to leave about $25 \%$ of unmined ore.

The major ground control issues encountered within this mining region are summarised further in Table 3 and shown in Figure 3. 
Table 3 Ground conditions encountered at Balaria's western lenses

\begin{tabular}{|c|c|c|}
\hline Pillar structures & Photograph & Ground conditions \\
\hline $\begin{array}{l}5 \mathrm{~W}-8 \mathrm{~W} \text { crown } \\
\text { pillar } 263 \mathrm{mRL} \\
\text { (marked 'I- III' } \\
\text { on Figure 3) }\end{array}$ & & $\begin{array}{l}\text { The crown of } 8 \mathrm{~W} \text { stope (marked 'III') spalled very } \\
\text { severely, accompanied by strong micro-seismic activities } \\
\text { in its mid-span followed by a collapse within } 48 \text { hours. } \\
\text { The phenomenon then extended towards both ends } \\
\text { when extraction in } 8 \mathrm{~W} \text { stope ( } 263-190 \mathrm{mRL} \text { ) was } \\
\text { completed in } 1993 \text {. }\end{array}$ \\
\hline $\begin{array}{l}\text { 9W } 263 \text { Crown } \\
\text { (marked 'IV' on } \\
\text { Figure 3) }\end{array}$ & N/A & $\begin{array}{l}\text { The } 9 \text { w crown, likewise, failed in } 1994 \text { progressively and } \\
\text { gradually. }\end{array}$ \\
\hline $\begin{array}{l}5 \text { W } 190 \text { Crown } \\
\text { (marked 'V' on } \\
\text { Figure 3) }\end{array}$ & & $\begin{array}{l}\text { The stope back spalled very severely and its lower } \\
\text { periphery arched by } 10 \mathrm{~m} \text { (165-175 mRL, marked VA) } \\
\text { during extraction of } 5 \mathrm{~W} \text { stope between } 190-120 \mathrm{mRL} \text {. } \\
\text { The roof of the drive at } 175 \mathrm{mRL} \text { (marked VA) present in } \\
\text { the pillar spalled very severely. Formation of micro-slabs } \\
\text { characterised the failure in the beginning and then } \\
\text { followed by macro-slabbing (Rajmeny et al. 2002). }\end{array}$ \\
\hline $\begin{array}{l}7 \mathrm{~W} 190 \text { Crown } \\
\text { (marked 'VI' on } \\
\text { Figure 3) }\end{array}$ & & $\begin{array}{l}\text { Similar to } 5 \mathrm{~W} \text { crown, the } 7 \mathrm{~W} \text { crown lower periphery also } \\
\text { arched by } 10 \mathrm{~m}(165-175 \mathrm{mRL}) \text { during the } 7 \mathrm{~W} \text { stope } \\
\text { extraction }(190-120 \mathrm{mRL}) \text {. }\end{array}$ \\
\hline $\begin{array}{l}\text { Rib 8W-9W } \\
\text { 263-190 } \\
\text { (marked 'VII' on } \\
\text { Figure 3) }\end{array}$ & & $\begin{array}{l}\text { The rib pillar severely spalled. The man-pass raise } \\
\text { experienced dog-erring along E-W direction (general mine } \\
\text { strike) and had to be abandoned for regular services } \\
\text { when the extraction of } 8 \mathrm{~W} \text { between } 190-120 \mathrm{mRL} \\
\text { reached final stage. }\end{array}$ \\
\hline $\begin{array}{l}7 \mathrm{~W}-8 \mathrm{~W} \text { rib } \\
190-120 \\
\text { (marked 'VIII' on } \\
\text { Figure 3) }\end{array}$ & & $\begin{array}{l}\text { Very severe spalling observed on } 7 \mathrm{~W} \text { stope side. Pillar } \\
\text { drives on } 7 \mathrm{~W} 155 \text { (marked VIIIA) and } 139 \mathrm{mRL} \text { (marked } \\
\text { VIIIB) spalled very severely } 1-1.5 \mathrm{~m} \text { high along with } \\
\text { borehole breakouts. The extraction in } 7 \mathrm{~W} \text { western part } \\
\text { had to be abandoned and about } 25 \% \text { ore, locked in } \\
\text { thicker rib, had to be abandoned. }\end{array}$ \\
\hline
\end{tabular}

\section{$3 \quad$ Numerical modelling}

\subsection{Background}

Rock mass failure due to induced stress is more complicated than gravity driven and predicting the failure zone is only possible when an improved understanding of the brittle behaviour of rocks around underground openings is attained (Hoek et al. 1995). The post-peak stress-strain behaviour of intact rocks and rock masses can be simplified to follow three distinctive mechanisms: perfectly brittle, strain-softening or strength weakening (brittle plastic) and ductile behaviour (perfectly plastic). 
Failure of massive brittle, hard rocks at low confining stress, as observed in rocks near the excavation boundary, generally occurs in a sudden and brittle manner resulting in spalling and slabbing seen at excavation surfaces.

Using continuum modelling approaches, Wagner (1987), Pelli et al. (1991), Castro et al. (1996), Martin (1997) and Grimstad and Bhasin (1996) have investigated the subject considering traditional failure criteria and assuming that the mobilisation of the cohesion and frictional strength components is instantaneous. As stated by Martin et al. (2001), this approach overlooks a key observation of brittle failure, which is the formation of tensile cracks is the first step in the failure process. The next stage, in the pre-peak failure process, is the crack interaction and the point of true yield. Falmagne (2002) and Diederichs (2000) demonstrated the concept that the cohesive strength component dominates at low strains and low confinement, whereas, the frictional strength component dominates at large strain and high confinement (Martin 1997).

At a fundamental level, when dealing with laboratory triaxial test results, Hoek and Brown (1980) reviewed several sets of laboratory test results and found that, unlike the traditional Mohr-Coulomb criterion, the peak failure envelope at different confinement levels follows a non-linear relationship in major and minor principal stress space. As a result, they proposed an empirical criterion, where material constant $\mathrm{m}$ and $\mathrm{s}$, and UCS of intact rock, represents the curvature and position of failure envelope.

To investigate the suitability of various constitutive material models to replicate the observed ground response at the Balaria mine, a FLAC3D numerical model was constructed, analysed and compared using four different material models as below:

- Linear Mohr-Coulomb with post-peak CSFS.

- Bi-linear Mohr-Coulomb with post-peak CSFS.

- Linear Mohr-Coulomb with post-peak CSFH.

- The IUCM proposed by Vakili (2016).

The model geometry was constructed according to the mine geometries around the western lenses described previously and is shown in Figure 4.

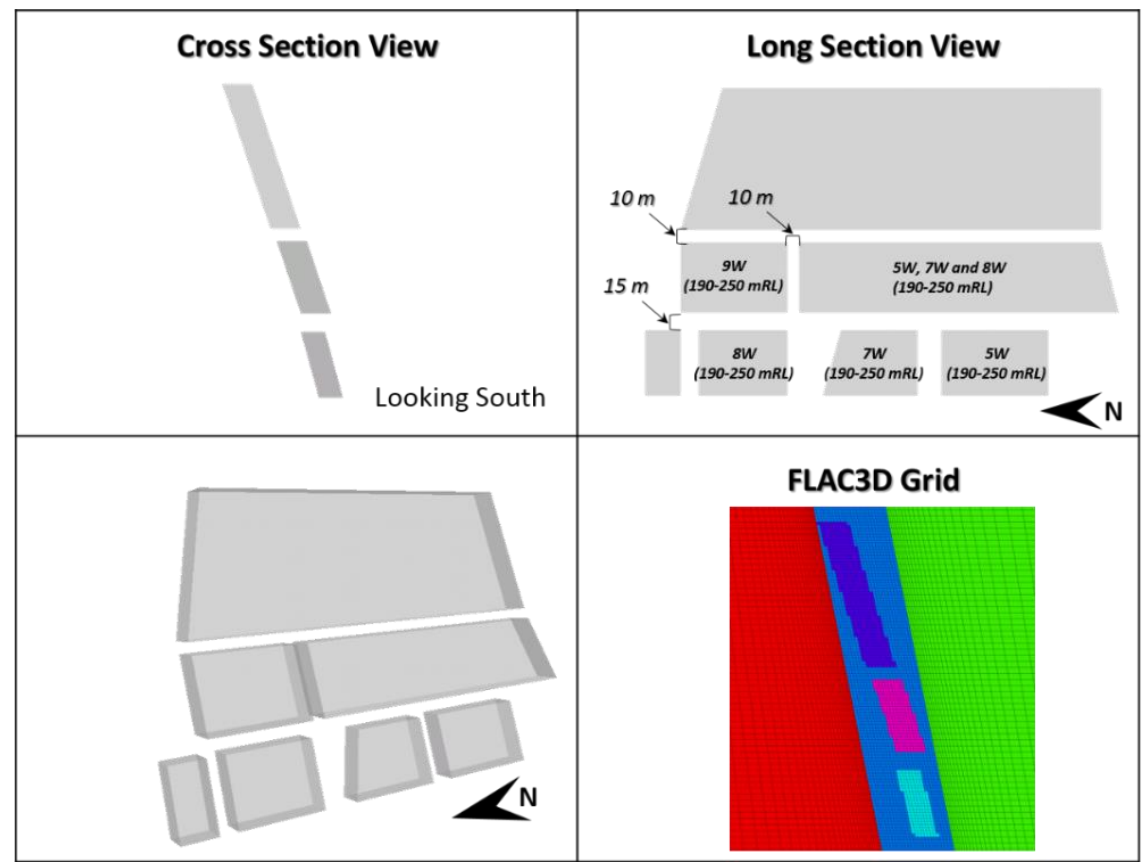

Figure 4 Constructed FLAC3D model geometry 
For interpretation of results, three model outputs including differential stress $\left(\sigma_{1}-\sigma_{3}\right)$, model velocity and volumetric strain were employed in the study. The model velocity provides an indication of numerical instability in the model with units of $\mathrm{m} /$ calculation step. The volumetric strain is the unit change in volume due to a deformation $\left(\Delta V / V_{0}\right)$ and is calculated by the sum of the major, minor, and intermediate principal strain components $\left(\varepsilon_{1}+\varepsilon_{2}+\varepsilon_{3}\right)$. A negative volumetric strain implies a contraction of the rock mass and a positive value indicates dilation. Contraction occurs at high confinement, while dilation happens with reduced lower confinement, such as near the boundary of excavation. The rock mass damage is most often controlled by a dilatational volumetric strain induced at low confinement levels. However, in cases of high confinement, rock can still become damaged (crushing), while undergoing contraction (negative volumetric strain). Therefore, it is always important that in continuum models, other parameters like velocity are monitored to aid in the interpretation of results. Vakili et al. (2014) provided a visual representation of various volumetric strains with respect to the degree of disintegration as simulated in a fully discontinuum model through modelling of uniaxial loading of a rock sample, as shown in Figure 5.

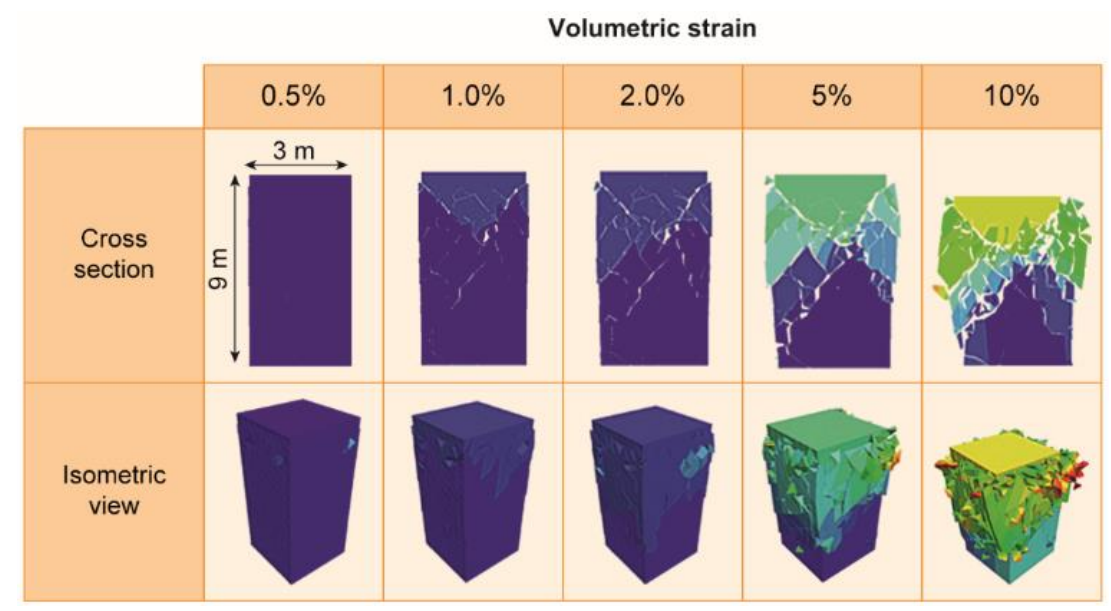

Figure 5 Visual representation of degree of rock disintegration at various levels of volumetric strain (after Vakili et al. 2014)

\subsection{Linear Mohr-Coulomb with post-peak CSFS}

The classical Mohr-Coulomb peak strength criterion and associated constitutive material models received wide acceptance and application in the field of geotechnical engineering. Despite its wide application, several research works and studies questioned its usefulness and accuracy for many rock mechanics problems. This is particularly more pounced when linear Mohr-Coulomb is used in an unsuitable modelling software code or when other fundamental failure processes like strain-softening, dilation, confinement dependency, anisotropy etc. are ignored. According to Brown (2008), the linear Mohr-Coulomb, consisting of two independent cohesive and frictional components, does not provide a realistic representation of the progressive failure and disintegration of rock under stress. Some published studies, such as Hajiabdolmajid et al. (2002), Barton and Pandey (2011), and Barton (2013), also highlighted the limitation of this model and its application to predict damage in the rock material.

The commercially available FLAC3D 'strain-hardening/softening' model (Itasca, 2013) was employed in this study to implement a constitutive behaviour incorporating linear Mohr-Coulomb for peak and CSFS for post-peak criterion.

A line-fitting procedure is most often used by practitioners to find equivalent cohesion and friction angle values based on the Hoek-Brown curves. This is commonly carried-out by employing Rocscience's RocLab/RockData software (Rocscience Inc. 2017). This procedure was used in this study to derive the required inputs for the peak failure state. The post-peak inputs, including residual properties and critical plastic strain (the strain limit when strength parameters reach their ultimate residual properties), were derived according to guidelines provided by Lorig and Varona (2013). The full list of input parameters assigned in the FLAC3D model are listed in Table 4. 
Table 4 Model input parameters used in the linear Mohr-Coulomb with post-peak CSFS model

\begin{tabular}{lllllllll}
\hline $\begin{array}{l}\text { Bulk } \\
\text { modulus } \\
(\mathrm{GPa})\end{array}$ & $\begin{array}{l}\text { Shear } \\
\text { modulus } \\
(\mathrm{GPa})\end{array}$ & $\begin{array}{l}\text { Cohesion } \\
(\mathrm{MPa})\end{array}$ & $\begin{array}{l}\text { Friction } \\
\text { angle } \\
\left.\mathbf{(}^{\circ}\right)\end{array}$ & $\begin{array}{l}\text { Tensile } \\
\text { strength } \\
(\mathrm{MPa})\end{array}$ & $\begin{array}{l}\text { Res. } \\
\text { cohesion } \\
(\mathrm{MPa})\end{array}$ & $\begin{array}{l}\text { Res. } \\
\text { friction } \\
\text { angle } \\
\left({ }^{\circ}\right)\end{array}$ & $\begin{array}{l}\text { Res. tensile } \\
\text { strength } \\
(\mathrm{MPa})\end{array}$ & $\begin{array}{l}\text { Critical } \\
\text { strain }\end{array}$ \\
\hline 12.8 & 8.5 & 8 & 38 & 0.34 & 0 & 33 & 0 & 0.0175 \\
\hline
\end{tabular}

Modelling outputs for the linear Mohr-Coulomb with CSFS for post-peak model is shown in Figure 6 . The following remarks can be made when comparing the modelling results and the actual rock mass response:

- The model results show the crown pillar of $5 \mathrm{~W}$ to $9 \mathrm{~W}$ stopes at $263 \mathrm{mRL}$ (marked I to IV), is de-stressed and having volumetric strain exceeding $5 \%$. However, except for the corners of the $8 \mathrm{~W}$ and $9 \mathrm{~W}$ stopes, the majority of the crown pillar shows not much velocity, suggesting that the pillar has softened and undergone damage but ultimately stabilised. This does not correlate well with the ultimate actual state of these crown pillars (collapsed condition).

- The model shows no signs of damage and volumetric strain is less than $0.2 \%$ within the crown pillar of $5 \mathrm{~W}$ to $9 \mathrm{~W}$ stopes at $190 \mathrm{mRL}$ (marked V and VI). This does not correlate well with the actual reported response (severe spalling but no hole-through/collapse).

- The model shows some signs of de-stressing, high velocities and more than $5 \%$ volumetric strain within the upper part of the rib pillar between the $8 \mathrm{~W}$ and $9 \mathrm{~W}$ stopes between 263 and $190 \mathrm{mRL}$ (marked VII). However, this does not correlate well with the actual reported response (side spalling but no hole-through/collapse of the pillar).

- The model shows no signs of damage within the rib pillar between the $8 \mathrm{~W}$ and $7 \mathrm{~W}$ stopes between 190 and $120 \mathrm{mRL}$ (marked VIII). This does not correlate with the actual reported response, which reported severe side spalling. However, it is possible that the observed spalling was geometry related (as shown in Figure 3), which could not be captured in simplified model geometries.

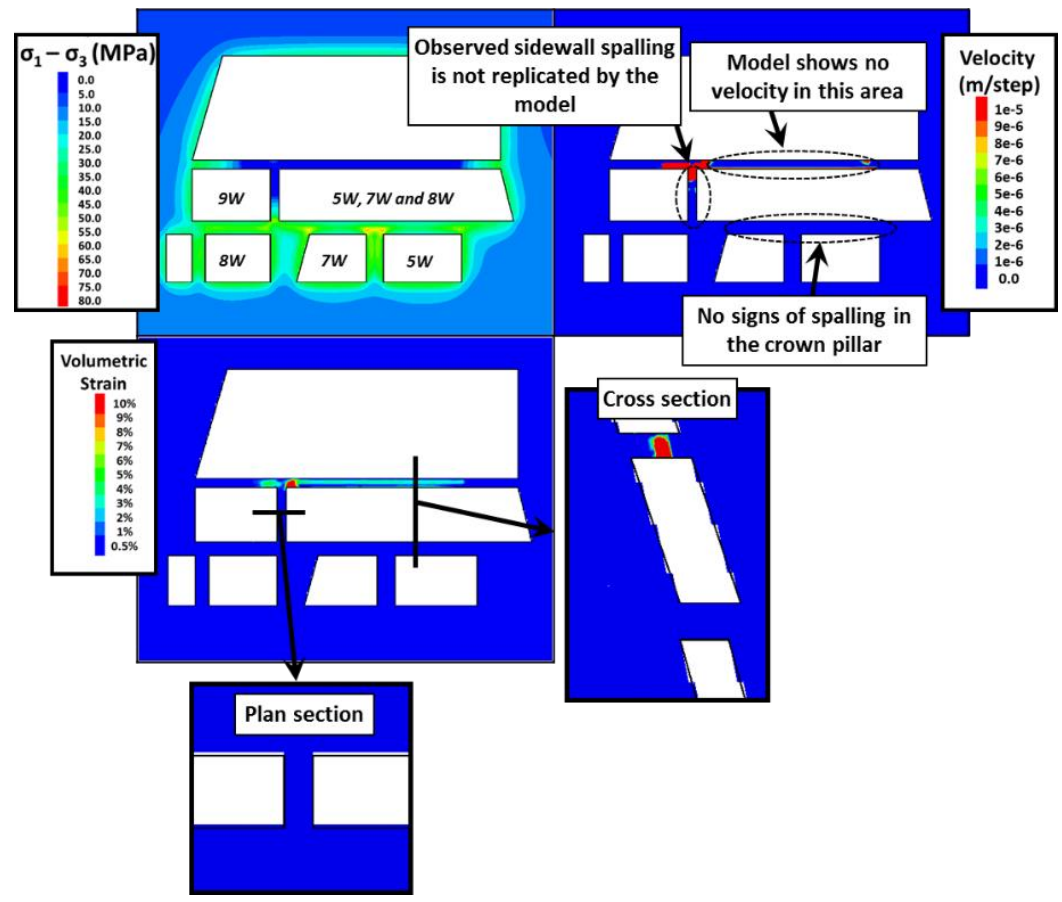

Figure 6 Model outputs for the linear Mohr-Coulomb with CSFS for post-peak model 


\subsection{Bi-linear Mohr-Coulomb with CSFS for post-peak}

To overcome the limitations of the linear Mohr-Coulomb failure criterion, some practitioners apply an improved peak failure criterion, which incorporates a bi-linear curve fitting procedure to obtain a better match to the Hoek-Brown failure criterion.

Sainsbury (2012) demonstrated that a bi-linear fit can provide a more accurate strength estimate over the range of expected stresses. Vakili et al. (2012) showed that a multi-linear Mohr-Coulomb peak failure criterion was sufficient to reproduce the observed excavation damage in a vertical shaft.

The commercially available FLAC3D 'bilinear strain-hardening/softening' model (Itasca, 2013) was then employed in the study to implement an improved constitutive behaviour incorporating bi-linear Mohr-Coulomb for peak and CSFS for post-peak criterion.

There is no set and consistent guideline for how the two segments of the bi-linear envelope are selected and inputs are often assigned based on users' experience and some calibration process. In this study, the two segments were chosen by best fitting to the Hoek-Brown curve and considering the maximum confinement expected in the problem area. The full list of input parameters assigned in the FLAC3D model are listed in Table 5. Note that the Segment 1 and 2 refer two lines that are fitted to a Hoek-Brown envelop each applicable to different confining stress ranges.

Table 5 Model input parameters used in the bi-linear Mohr-Coulomb with CSFS for post-peak model

\begin{tabular}{|c|c|c|c|c|c|c|c|c|c|c|}
\hline \multirow{2}{*}{$\begin{array}{l}\text { Bulk } \\
\text { modulus } \\
\text { (GPa) }\end{array}$} & \multirow{2}{*}{$\begin{array}{l}\text { Shear } \\
\text { modulus } \\
\text { (GPa) }\end{array}$} & \multicolumn{2}{|c|}{$\begin{array}{l}\text { Cohesion } \\
\text { (MPa) }\end{array}$} & \multicolumn{2}{|c|}{$\begin{array}{l}\text { Friction angle } \\
\left({ }^{\circ}\right)\end{array}$} & \multirow{2}{*}{$\begin{array}{l}\text { Tensile } \\
\text { strength } \\
\text { (MPa) }\end{array}$} & \multirow{2}{*}{$\begin{array}{l}\text { Res. } \\
\text { cohesion } \\
(\mathrm{MPa})\end{array}$} & \multirow{2}{*}{$\begin{array}{l}\text { Res. } \\
\text { friction } \\
\text { angle } \\
\left({ }^{\circ}\right)\end{array}$} & \multirow{2}{*}{$\begin{array}{l}\text { Res. } \\
\text { tensile } \\
\text { strength } \\
\text { (MPa) }\end{array}$} & \multirow[t]{2}{*}{$\begin{array}{l}\text { Critical } \\
\text { strain }\end{array}$} \\
\hline & & $\begin{array}{l}\text { Segment } \\
1\end{array}$ & $\begin{array}{l}\text { Segment } \\
2\end{array}$ & $\begin{array}{l}\text { Segment } \\
1\end{array}$ & $\begin{array}{l}\text { Segment } \\
2\end{array}$ & & & & & \\
\hline 12.8 & 8.5 & 6 & 8 & 44 & 38 & 0.34 & 0 & 33 & 0 & 0.0175 \\
\hline
\end{tabular}

Modelling outputs for the bi-linear Mohr-Coulomb with post-peak CSFS model is shown in Figure 7. The following remarks can be made when comparing the modelling results and the actual rock mass response observations:

- The model shows de-stressing, high velocities and more than $10 \%$ volumetric strain within the crown pillar of $5 \mathrm{~W}$ to $9 \mathrm{~W}$ stopes at $263 \mathrm{mRL}$ (marked I to IV). This correlates well with ultimate actual state of these crown pillars (collapsed condition).

- The model shows no signs of damage within the crown pillar of 5W to $9 \mathrm{~W}$ stopes at $190 \mathrm{mRL}$ (marked $\mathrm{V}$ and $\mathrm{VI}$ ). This does not correlate well with the actual reported response (severe spalling but no hole-through/collapse).

- The model shows de-stressing, high velocities and more than $10 \%$ volumetric strain within the upper part of rib pillar between the 8W and 9W stopes between 263 and 190 mRL (marked VII). This does not correlate with the actual reported response (side spalling but no hole-through/collapse of the pillar).

- The model shows no signs of damage within the rib pillar between the $8 \mathrm{~W}$ and $7 \mathrm{~W}$ stopes between 190 and $120 \mathrm{mRL}$ (marked VIII). This does not correlate with the actual reported response, which reported severe side spalling. However, it is possible that the observed spalling was geometry related (as shown in Figure 3), which could not be captured in the simplified model geometries. 


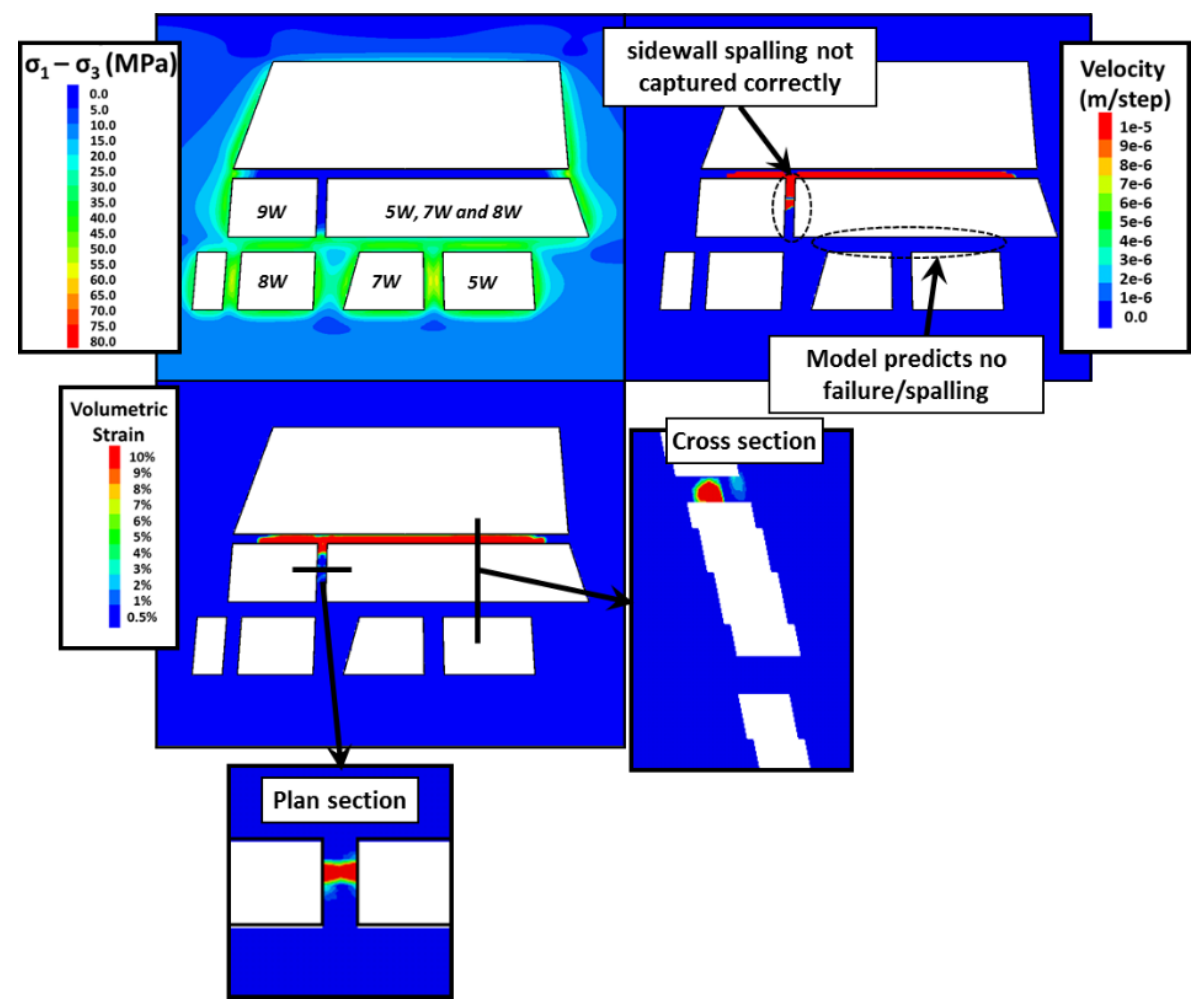

Figure 7 Model outputs for the bi-linear Mohr-Coulomb with post-peak CSFS model

\subsection{Linear Mohr-Coulomb with post-peak cohesion-softening/friction-hardening}

Hajiabdolmajid (2001), adopted a cohesion-weakening and friction-strengthening criterion to predict the extent and depth of brittle failure of rocks. Similarly, Martin et al. (2001) used a model with cohesion-weakening and friction-hardening as a function of plastic strain implemented in the FLAC code to numerically model the shape and extent of brittle failure for Atomic Energy Canada Limited (AECL) mine-by test tunnel constructed in Lac du Bonnet granite.

More recently, the western part of the Mochia mine was numerically modelled using an approach suggested by Barton, which employs a CSFH material behaviour (Barton \& Pandey 2011) referred to as the $Q_{c}$ formulation. The $Q_{c}$ formulation (i.e. cohesion component (cc) and frictional component (fc)) are extracted directly from the geotechnical logging of recovered core for $Q$. The Q-based approach also uses a depth dependent elastic modulus.

The $Q_{c}$ formulation can be determined as:

$$
\begin{gathered}
C C=\frac{R Q D}{J n} \cdot \frac{1}{S R F} \cdot \frac{\sigma_{c}}{100} \\
f c=\tan ^{-1}\left(\frac{J r}{J a} \cdot J w\right)
\end{gathered}
$$

Barton and Pandey (2011) used Q values logged in Mochia and have utilised the $Q_{c}$ formulation as a potential source for peak cohesive and frictional strength. These values, are softened or mobilised to residual cohesion and peak frictional strength, respectively.

The commercially available FLAC3D 'strain-hardening/softening' model (Itasca, 2013) was employed in this study to implement the CSFH model.

The guidelines outlined by Barton and Pandey (2011) were used to derive the input and implement the post-peak behaviour. The full list of input parameters assigned in the FLAC3D model are listed in Table 6. 
Table 6 Model input parameters used in the linear Mohr-Coulomb with cohesion-softening/ friction-hardening for post-peak model

\begin{tabular}{lllllllll}
\hline $\begin{array}{l}\text { Bulk } \\
\text { modulus } \\
(\mathrm{GPa})\end{array}$ & $\begin{array}{l}\text { Shear } \\
\text { modulus } \\
(\mathrm{GPa})\end{array}$ & $\begin{array}{l}\text { Cohesion } \\
(\mathrm{MPa})\end{array}$ & $\begin{array}{l}\text { Initial } \\
\text { friction } \\
\text { angle } \\
\left({ }^{\circ}\right)\end{array}$ & $\begin{array}{l}\text { Peak } \\
\text { friction } \\
\text { Angle } \\
\left({ }^{\circ}\right)\end{array}$ & $\begin{array}{l}\text { Tensile } \\
\text { strength } \\
(\mathrm{MPa})\end{array}$ & $\begin{array}{l}\text { Residual } \\
\text { cohesion } \\
(\mathrm{MPa})\end{array}$ & $\begin{array}{l}\text { Residual } \\
\text { friction } \\
\text { angle } \\
\left({ }^{\circ}\right)\end{array}$ & $\begin{array}{l}\text { Residual } \\
\text { tensile } \\
\text { strength } \\
(\mathrm{MPa})\end{array}$ \\
\hline 27.2 & 16.3 & 17 & 10 & 76 & 4.3 & 4.0 & 54 & 0.0 \\
\hline
\end{tabular}

Modelling outputs for the linear Mohr-Coulomb with CSFH for post-peak model are shown in Figure 8.

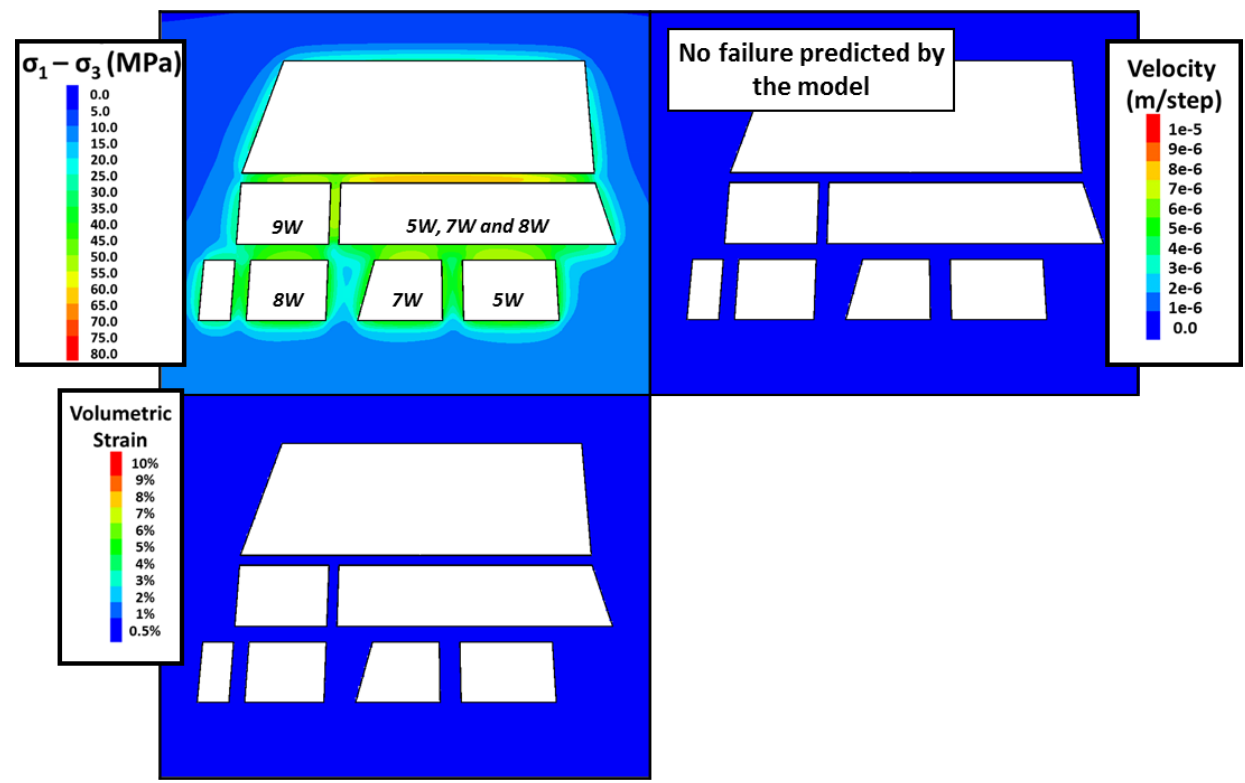

Figure 8 Model outputs for the linear Mohr-Coulomb with cohesion-softening/friction-hardening for post-peak model

Although the differential stress plot shows increased differential stress within the crown pillar of $5 \mathrm{~W}$ to $9 \mathrm{~W}$ stopes at $263 \mathrm{mRL}$, the model shows no signs of damage in any area of the mined regions, suggesting that the proposed approach was not able to replicate the rock mass behaviour at the Balaria mine.

\subsection{The improved unified constitutive model}

The IUCM gathers the most notable and widely accepted previous research work in the area of rock mechanics and integrates them into a unified constitutive model that can better and more accurately predict the stress-strain relationships in a continuum model. Full details regarding the theoretical backgrounds, guidelines for selection of the inputs, validation, and limitations/assumptions for this model are provided by Vakili (2016).

In developing this model, the use of any new theory or technique was avoided where possible, and all the adopted processes were based on accepted and widely applied rock mechanics techniques and theories.

A key advantage of the IUCM is that it accounts for all important and fundamental aspects of rock failure from simple to more complex ones in a unified model. These aspects include the transition from brittle to ductile response, confinement-dependent strain-softening, dilatational response, strength anisotropy, and stiffness softening.

The IUCM is a commercially available model (Vakili, 2016) and is currently implemented in Itasca's FLAC3D code as a FISH function and a C++ DLL plugin. It is also a FISH function in Itasca's 3DEC code.

The guidelines outlined by Vakili (2016) were used to derive the input parameters for the IUCM model. An important advantage of the IUCM is that the rock mass properties, post-peak behaviour, dilatational 
response and residual properties are automatically controlled and assigned according to rock mass characterisation (GSI) and intact laboratory test results (UCS, $\mathrm{m}_{\mathrm{i}}$ and $\mathrm{E}_{\mathrm{i}}$ ) that are often readily available. The full list of input parameters assigned in the FLAC3D model are listed in Table 7.

Table 7 Model input parameters used in the improved unified constitutive model

\begin{tabular}{llll}
\hline $\begin{array}{l}\text { UCS of intact rock } \\
\text { (MPa) }\end{array}$ & $\begin{array}{l}\text { GSI of the } \\
\text { rock mass }\end{array}$ & $\begin{array}{l}\text { Hoek-Brown constant } m_{i} \\
\text { for the intact rock matrix }\end{array}$ & $\begin{array}{l}\text { Elastic modulus of } \\
\text { intact rock (GPa) }\end{array}$ \\
\hline 117 & 60 & 17 & 40 \\
\hline
\end{tabular}

Modelling outputs for the IUCM are shown in Figure 9.

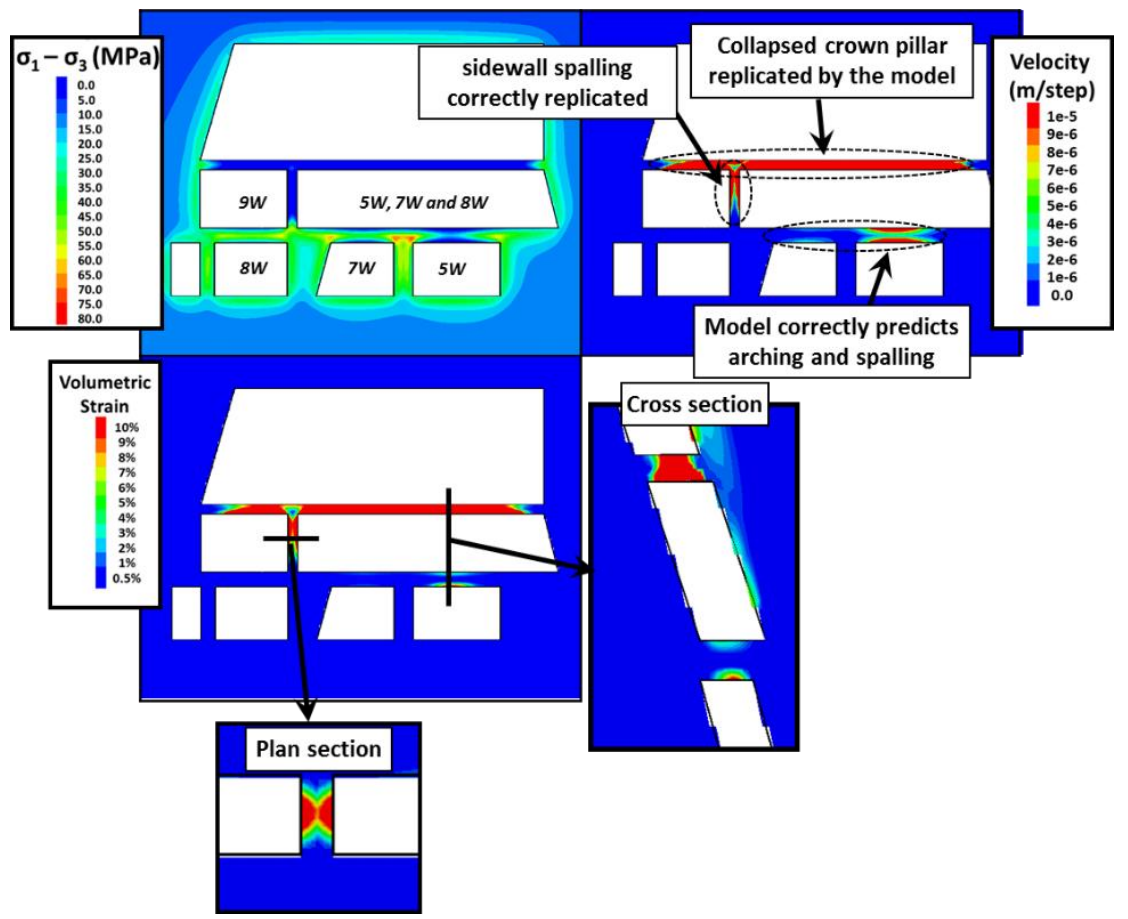

Figure 9 Model outputs for the linear Mohr-Coulomb with post-peak cohesion-softening/ friction-hardening model

The following remarks can be made when comparing the modelling results and the actual rock mass response:

- The model shows de-stressing, high velocities and more than $10 \%$ volumetric strain within the crown pillar of $5 \mathrm{~W}$ to $9 \mathrm{~W}$ stopes at $263 \mathrm{mRL}$ (marked I to IV). This correlates with the actual state of these crown pillars (collapsed condition).

- The model shows de-stressing, high velocities and up to $10 \%$ volumetric strain within the lower periphery of the crown pillar of $5 \mathrm{~W}$ to $9 \mathrm{~W}$ stopes at $190 \mathrm{mRL}$ (marked $\mathrm{V}$ and $\mathrm{VI})$. This correlates well with the actual reported response (severe spalling but no hole-through/collapse). In addition, the observed arching mechanism was replicated by the model.

- The model shows de-stressing, high velocities and up to $10 \%$ volumetric strain within the side walls of the rib pillar between the $8 \mathrm{~W}$ and $9 \mathrm{~W}$ stopes between 263 and $190 \mathrm{mRL}$ (marked VII). This correlates with the actual reported response (side spalling but no hole-through/collapse of the pillar).

- The model shows no signs of damage within the rib pillar between the $8 \mathrm{~W}$ and $7 \mathrm{~W}$ stopes between 190 and $120 \mathrm{mRL}$ (marked VIII). This does not correlate with the actual reported response, which reported severe side spalling. However, it is possible that the observed spalling was geometry related (as shown in Figure 3), which could not be captured in simplified model geometries. 


\section{$4 \quad$ Concluding remarks}

Rock response at the Balaria mine situated in competent dolomite horizons and subjected to intermediate to high stress environment was simulated, using four types of constitutive material models: linear Mohr-Coulomb with post-peak CSFS, bi-linear Mohr-Coulomb with post-peak CSFS, Mohr-Coulomb with post-peak CSFH, and IUCM.

The results of all approaches have been compared with actual ground conditions. This revealed that the numerical models using the IUCM provided the most realistic match to the observations in the mine, including failure of the crown pillars.

The key findings from each analysed case are:

- Using linear Mohr-Coulomb with CSFS for post-peak, the model was not able to accurately predict the observed rock mass response in any of the mine pillars. This model showed elevated volumetric strain and de-stressing in the crown pillar of the $5 \mathrm{~W}$ to $9 \mathrm{~W}$ stopes at $263 \mathrm{mRL}$ but very little to no velocity magnitude, suggesting that that the pillar has softened and undergone damage but ultimately stabilised (unlike the real-life observations where the pillar collapsed).

- Using bi-linear Mohr-Coulomb with CSFS post-peak, the model was able to accurately predict the observed rock mass response in the crown pillar of the $5 \mathrm{~W}$ to $9 \mathrm{~W}$ stopes at $263 \mathrm{mRL}$. However, it was not able to capture the observed mechanism in other rib and crown pillars within the area of study.

- Using Mohr-Coulomb with CSFH post-peak, the model was not able to accurately predict the observed rock mass response in any of the mine pillars. The differential stress plot showed increased differential stress within the crown pillar of $5 \mathrm{~W}$ to $9 \mathrm{~W}$ stopes at $263 \mathrm{mRL}$, but the model showed no signs of damage in any area of the mined regions suggesting that the proposed approach was not able to replicate the rock mass behaviour at the Balaria mine.

- Using IUCM, the model was able to accurately predict most of the observed rock mass response at the Balaria mine. This includes, accurate prediction of collapse in the crown pillar of the $5 \mathrm{~W}$ to $9 \mathrm{~W}$ stopes at $263 \mathrm{mRL}$, accurate prediction of sidewall spalling within the rib pillar between the $8 \mathrm{~W}$ and $9 \mathrm{~W}$ stopes between 263 and $190 \mathrm{mRL}$ and accurate prediction of arching and spalling within the lower periphery of the crown pillar of $5 \mathrm{~W}$ to $9 \mathrm{~W}$ stopes at $190 \mathrm{mRL}$.

It can be argued that results for individual constitutive models could have been improved if a range of input parameters were used instead of single input values. However, the purpose of this study was to understand how close the estimation accuracy is if expected values from laboratory tests and rock mass characterisation are applied. In other words, if a suitable constitutive model is used, the model should provide an adequate prediction of rock mass response when using the expected inputs derived directly from laboratory testing and rock mass characterisation. Also, in most cases analysed in this study the less suitable constitutive models were not able to capture the correct failure mechanism and its progressive nature. In this case, variation of the input parameters would not improve the estimation accuracy of the failure mechanism but, instead, just increase or decrease the severity of the failure.

None of the analysed constitutive models were able to replicate the spalling mechanism for the rib pillar between the $8 \mathrm{~W}$ and $7 \mathrm{~W}$ stopes between 190 and $120 \mathrm{mRL}$. However, it is possible that the observed spalling was geometry related. The geometry of the $7 \mathrm{~W}$ was simplified within the numerical models and this might have influenced the accuracy of the results.

This paper once again highlights the importance and significance of choosing the appropriate constitutive model when applying continuum numerical modelling for mine design purposes. Simplified constitutive models may provide acceptable estimate of the rock mass response in less complex ground conditions and/or strain paths. However, when more complex ground conditions exits (such as elevated stress levels, anisotropy and brittle intact rock failure) then a more accurate and rigorous constitutive model should be applied. 


\section{References}

Barton, N, 2013, 'Shear strength criteria for rock, rock joints, rockfill and rock masses: Problems and some solutions', Journal of Rock Mechanics and Geotechnical Engineering, vol. 5, no. 4, pp. 249-261.

Barton, N, Pandey, SK 2011, 'Numerical modeling of two stoping methods in two Indian mines using degradation of c and mobilization of phi based on Q-parameters', International Journal of Rock Mechanics and Mining Sciences, vol. 48, no. 7, pp. 1095-1112.

Bieniawski, ZT 1989, Engineering Rock Mass Classifications: A Complete Manual for Engineers and Geologists in Mining, Civil, and Petroleum Engineering, John Wiley \& Sons.

Brown, ET 2008, 'Estimating the mechanical properties of rock masses', in Y Potvin, J Carter, A Dyskin \& R Jeffrey (eds), Proceedings of the 1st Southern Hemisphere International Rock Mechanics Symposium: SHIRMS, vol. 1, 16-18 September 2008, Perth, Australian Centre for Geomechanics, Perth, pp. 3-21.

Castro, L, McCreath, D \& Oliver, P 1996, 'Rock mass damage initiation around the Sudbury Neutrino Observatory Cavern', Proceedings of the 2nd North American Rock Mechanics Symposium, vol. 2, Balkema, Rotterdam, pp. 1589-1595.

Diederichs, MS 2000, Instability of Hard Rockmasses: The Role of Tensile Damage and Relaxation, PhD thesis, University of Waterloo, Waterloo, pp. 566.

Falmagne, V 2002, Quantification of rock mass degradation using microseismic monitoring and application for mine design, PhD thesis, Queen's University, Kingston, pp. 424.

Grimstad, E \& Bhasin, R 1996, 'Stress strength relationships and stability in hard rock', Proceedings of the Conference of Recent Advances in Tunnelling Technology, vol. 1, New Delhi, pp. 3-8.

Hajiabdolmajid, VR 2001, Mobilization of Strength in Brittle Failure of Rock, PhD thesis, Queen's University, Kingston.

Hajiabdolmajid, VR, Kaiser PK \& Martin, CD 2002, 'Modelling brittle failure of rock', International Journal of Rock Mechanics and Mining Sciences, vol. 39, pp. 731-741.

Hoek, E \& Brown, ET 1980, 'Empirical strength criterion for rock masses', Journal of Geotechnical Engineering Division, vol. 106, no. GT9, pp. 1013-1035.

Hoek, E, Carranza-Torres, C \& Corkum, B 2002, 'Hoek-Brown failure criterion - 2002 edition', in R Hammah, W Bawden, J Curran \& M Telesnicki (eds), Proceedings of the NARMS-TAC Conference: Mining, Innovation and Technology, vol. 1, pp. 267-273.

Hoek, E, Kaiser, PK \& Bawden, WF 1995, Support of Underground Excavations in Hard Rock, 3rd edn, Taylor \& Francis, Rotterdam.

Itasca 2013, FLAC3D, version 5.01, Itasca Consulting Group, Inc., Minneapolis.

Lorig, L \& Varona, P 2013, 'Guidelines for numerical modelling of rock support for mines', in Y Potvin \& B Brady (eds), Proceedings of the Seventh International Symposium on Ground Support in Mining and Underground Construction, Australian Centre for Geomechanics, Perth, 13-15 May 2016, pp. 81-105.

Martin, CD 1997, 'The effect of cohesion loss and stress path on brittle rock strength', Canadian Geotechnical Journal, vol. 34, pp. 698-725.

Martin, CD, Christiansson, R \& Soderhall, J 2001, Rock stability considerations for siting and constructing a KBS-3 repository, Technical Report TR-01-38, Swedish Nuclear Fuel and Waste Management Company, Stockholm.

Pelli, F, Kaiser, PK \& Morgenstern, NR 1991, 'An interpretation of ground movements recorded during construction of Donkin-Morien tunnel', Canadian Geotechnical Journal, vol. 28, pp. 239-254.

Rajmeny, PK, Singh, UK, Rathore, SS 2002, 'Predicting failure of boreholes and drives adjacent to open stopes in Indian mines with high stress', International Journal of Rock Mechanics and Mining Science, vol. 39, no. 2, pp. 151-164.

Rocscience Inc. 2017, RocData, Rocscience Inc., Toronto, viewed 25 January 2017, www.rocscience.com/rocscience/ products/rocdata

Rummel, F 2005, Rock Mechanics with Emphasis on Stress, Balkema, Rotterdam, pp. 37-42.

Sainsbury, BA 2012, 'A model for cave propagation and subsidence assessment in jointed rock masses', PhD thesis, The University of New South Wales, Kensington.

Vakili, A 2016, 'An improved unified constitutive model for rock material and guidelines for its application in numerical modelling', Computers and Geotechnics, vol. 80, pp. 261-282.

Vakili, A, Albrecht, J \& Sandy, M 2014, 'Rock strength anisotropy and its importance in underground geotechnical design', Proceedings of the Third Australasian Ground Control in Mining Conference, The Australasian Institute of Mining and Metallurgy, Carlton South, pp. 167-180.

Vakili, A, Sandy, M \& Albrecht, J 2012, 'Interpretation of non-linear numerical models in geomechanics-a case study in the application of numerical modelling for raise bored shaft design in a highly stressed and foliated rock mass', Proceedings of the 6th International Conference and Exhibition on Mass Mining, Canadian Institute of Mining, Metallurgy and Petroleum, Sudbury.

Wagner, H 1987, 'Design and support of underground excavations in highly stressed rock', Proceedings of the 6th ISRM Congress on Rock Mechanics, vol. 3, Balkema, Rotterdam, pp. 1443-1457. 